\title{
14 \\ PLAN COLOMBIA AND THE U.S. ARMY'S 7TH SPECIAL FORCES GROUP
}

\author{
Kevin M. Higgins ${ }^{1}$
}

"If I could live my life over again, I would come back as a captain in the 7th Special Forces Group," Lieutenant General Wayne Downing said. "There is no better job in the world." Downing made these remarks in October 1991, as the two of us ran down the sand trails and through the pine forest of Fort Bragg's "MATA Mile" fitness trail. ${ }^{2}$ This is how Ranger Downing did annual performance counseling. No office chat for him. It was a 10-kilometer run at dawn. ${ }^{3}$

Downing commanded U.S. Army Special Operations Command from August 1991 to April 1993. As the second commander of the relatively new headquarters, he was responsible for all of the Army's Special Operations Forces, including the Special Forces Groups, the 75th Ranger Regiment, the 160th Special Operations Aviation Regiment, and civil affairs and psychological operations forces. ${ }^{4}$

As commander, he traveled the globe to see his units in action. He was particularly impressed by the 7th Special Forces Group and its 12-man detachments, deployed throughout Central and South America to support the "War on Drugs." The teams trained and advised the antinarcotics police in the source zone countries from where virtually all of the world's cocaine originated. The Special Forces teams had autonomy, responsibility, and a critical mission in high-threat areas. "This is where the rubber meets the road," Downing remarked as the UH-60 helicopter skimmed the treetops of the Peruvian jungle on his way to visit a 7 th Group detachment. ${ }^{5}$

This chapter recounts how the 7th Special Forces Group deployed to Latin America to train the Andean Ridge police units from 1987 to 2003. It describes the relationship of the 7th Group with U.S. Southern Command (SOUTHCOM), the Department of State, and the Drug Enforcement Administration (DEA), covering the creation of the Special Forces Tactical Analysis Teams and Joint Planning and Assistance Teams.

It then provides a detailed case study of Colombia, providing the inside story of how the 7th Group helped to organize, train, equip, and advise a new Colombian Army counterdrug brigade. In 2000, this support evolved into Plan Colombia, a $\$ 1.3$-billion program that ultimately contributed to a successful end of the 50-year war with the Revolutionary Armed Forces of Colombia (FARC). ${ }^{6}$

\section{7th Group deploys to train Andean Ridge police units}

In 1986, the U.S. State Department requested help from the Department of Defense to establish and train the Andean Ridge antinarcotics police units. These Bolivian, Peruvian, Ecuadoran, and Colombian police units would interdict cocaine and precursor chemical shipments, destroy cocaine labs, and eradicate coca 
fields. ${ }^{7}$ Attacking cocaine in the source zone was a vital pillar of President Ronald Reagan's strategy for the "War on Drugs." The White House considered source zone operations a high-impact, economy-of-force mission. In 1989, DEA Special Agent Larry Leveron explained the importance of the source zone:

We added up the cost of all the man-hours and resources that the U.S. local and federal law enforcement officers spend to interdict cocaine domestically, inside the USA. It averaged out to $\$ 16,000$ for every gram of cocaine seized. Here in Bolivia, the DEA can pay an informant $\$ 2,500$ to take the antinarcotics police to a cocaine lab or cache site. We can seize upwards of two tons of pure cocaine on a single operation. This is much easier than hunting cocaine down in the USA. The narcos split that ton up into a thousand packets and spread it over 10 counties. ${ }^{8}$

SOUTHCOM's force of choice to train the Andean Ridge police units was the 7th Group. The 7th Group's principal mission in Latin America was foreign internal defense. In the 1980s, the Group successfully advised El Salvador, Honduras, and Costa Rica in their counterinsurgency efforts against armed Marxist subversive movements. During this time, the Group had honed Spanish language capabilities, cultural awareness, and instructor skills.

At the time, some members of the United States Congress and other critics questioned the appropriateness of an elite military unit like the 7th Group training civilian police forces. During the 1970s, some Latin American military and police forces had used harsh repressive measures against their citizens. Critics did not want the United States to encourage Latin American governments to militarize their police. ${ }^{9}$

Proponents of the 7th Group option countered that this training would complement the host nation's own formal police training. The Andean Ridge antinarcotics forces were first police, trained in their country's laws and police procedures. The 7th Group training would provide the forces the additional skills they needed to be successful against armed criminals operating in remote rural areas or high-risk urban neighborhoods. ${ }^{10}$

The Group's training focused on patrolling, marksmanship, immediate-action drills, land navigation, river crossings, mountaineering, first aid, survival skills, airmobile operations, mission planning, and human rights. These subjects were not part of police training, but they were necessary for the counterdrug mission, and the expertise resided within U.S. Special Forces. The Group designed training and practical exercises to conform to the host nation police's laws, protocols, use of force, and rules of engagement.

\section{Prelude to Colombia: 7th Group a key component of counternarcotics efforts in the Andean region}

In April 1987, Captain Charles T. Cleveland, the commander of Special Forces Operational Detachment Alpha (ODA) $774,{ }^{11}$ began the first mission into the Andean Ridge. His mission was to "to train an existing Bolivian counternarcotic police force in jungle light infantry operations; build a base camp to support sustainment, training, and operations; and [make them an] effective unit" and "assist the DEA in putting pressure on the drug networks in Bolivia's main coca-growing area, the Chapare region." ${ }^{2}$

To accomplish the mission, Cleveland traveled down dirt roads deep into the Chapare coca-growing region with officers from Bolivia's Mobile Police Unit for Rural Areas, the Unidad Móvil Policial para Áreas Rurales. Cleveland pulled up to an open field and threw his rucksack down. "This is our training camp," he said. "We start tomorrow."."13

Cleveland named the 40-day course Garras de Leopardo (Claws of the Leopard) after the jungle leopard indigenous to the Chapare. ${ }^{14}$ As ODA 774 taught the first iterations of the Garras course, the U.S. State Department built the school's barracks, mess hall, classrooms, and warehouses on Cleveland's empty field. Over the next few years, the 7th Group transitioned from teaching the course to training the trainers. By 
1991, the Bolivians were running the Garras center under 7th Group mentorship. ${ }^{15}$ Today, the site, now known as Garras de Valor, is an International Training Center, boasting graduates from 13 Latin American countries. ${ }^{16}$

The Garras course made the mobile police unit the best-trained and equipped unit in Bolivia. They were an ideal strike force for the DEA intelligence-driven counternarcotics operations. Many of the 7th Group captains and their ODAs would follow in Cleveland's footsteps over the years. They would establish training centers and elite units throughout the hemisphere.

In 1989, Captain Bennet Sacolick, commander of ODA 773, and Captain Ed Reeder, commander of ODA 784, deployed to Mazamari, Peru, to train the Peruvian National Police Sinchis. The Sinchis, Latin America's only airborne police unit, operated in the jungle highlands of Junin Department. The Maoist insurgent group, Shining Path (Sendero Luminoso), controlled Junin's extensive coca cultivations. Sacolick and Reeder taught the Sinchis a series of courses modeled after Cleveland's Garras de Leopardo. The DEA worked with the Sinchis on several successful counternarcotics operations. ${ }^{17}$

At the same time, Captain Bob Closson conducted an assessment of the Colombian National Police's counternarcotics bases. Closson developed a unit training strategy and recommendations for security upgrades. He laid the groundwork for 7th Group's 30-year relationship with the Colombian Antinarcotics Police, the Jungla Comandos. By 1992, the 7th Group soldiers were deploying on 135 missions a year to 17 countries in Latin America. Half of these missions focused on developing special counternarcotics police forces.

\section{Special Forces Tactical Analysis Teams}

In Bolivia, the DEA and the 7th Group developed a successful partnership model that was later implemented in more than 10 Latin American countries. The DEA attaché in Cartagena, Colombia, best described the relationship between the DEA and the Special Forces teams: "The DEA focuses on doing good things. Special Forces focuses on doing things good." ${ }^{18}$ The DEA wanted success in the drug war, and the 7th Group sought to produce a unit capable of achieving success.

The DEA helped the host nation with intelligence, analysis, investigations, judicial arrest, and search warrants. The DEA put the "X" on the map. The 7th Group ensured that the strike force could select the best route, navigate, move in a tight formation, cross obstacles, achieve surprise, and capture (or kill, if necessary) the target. After each mission, the 7th Group trainers conducted an after-action review with their counterparts. The trainers incorporated these lessons into the next training course. The Group discovered that missions most often failed due to faulty or incomplete information in the target folders as opposed to training shortfalls.

"We can help with that," exclaimed Master Sergeant Stan Brown to the DEA team in Chapare, Bolivia, in 1989. "We have [intelligence sergeants] on our team. They are well trained in preparing target folders and analyzing information." ${ }^{19}$ Brown assigned two members of the training team to the DEA planning cell. The Special Forces assistant operations and intelligence sergeants helped the DEA construct target folders, which included imagery, coordinates, threat assessment, and terrain study. This gave the Bolivians the tools needed to plan a successful mission. As a result, mission success increased, and the DEA asked SOUTHCOM to formalize and expand this intelligence planning support to all the Andean countries.

These teams were named Tactical Analysis Teams (TATs), which were defined as "an ad hoc organization developed with the mission associated with U.S. interests with a particular country or region in mind." ${ }^{20}$ They were "the focal point of the fusion of tactical intelligence from national, theater, and local assets" and their primary mission was to funnel "intelligence support to the host government." ${ }^{21}$ In addition to training counternarcotics units, the 7th Group support expanded to include two-man TATs in more than 10 Latin American countries. 


\section{Special Forces Joint Planning and Assistance Teams}

As counternarcotics training and operational missions increased, the Military Groups - the military component of the country team at the U.S. Embassies-were soon overwhelmed. The Military Group is the liaison between the Department of Defense and the host nation. It serves as the military advisor to the U.S. ambassador and the central coordinating agency for military operations and training.

The rapid surge in counternarcotics training and support was too much for the small Military Group offices to handle, so they turned to the 7th Group for help. The Special Forces soldiers had demonstrated a mature, professional, can-do attitude in the hinterlands, so the Military Groups asked SOUTHCOM for a six-man Special Forces element to augment their staff as the Joint Planning and Assistance Team (JPAT). The JPAT would coordinate the deployments for all U.S. military service members and typically rotate every six months.

In the early 1990s, the U.S. Marine Corps launched teams to develop a riverine interdiction capability in the Andean region. The narcos built their cocaine labs along riverbanks and used small boats and canoes to move precursor chemicals and cocaine up and down the rivers. The rivers served as the roads in the undeveloped territories. Like the 7th Group, the small Marine Corps training teams created these riverine units from scratch. SOUTHCOM provided the boats, weapons, fuel, and field gear, while the U.S. Army Corps of Engineers constructed the docks and the riverine outposts.

The U.S. Navy and Coast Guard partnered with host nation naval forces to interdict maritime traffic. The narcos moved loads of more than 500 kilograms of cocaine using go-fast boats and semi-submersible craft. Two-man crews piloted these small fiberglass vessels. The go-fasts achieved speeds of more than 40 knots while maintaining a low surface profile to avoid visual or radar detection.

The U.S. Air Force helped create the Air Bridge Denial program beginning in 1995. They enhanced the host nation air force's ability to detect and interdict illegal aircraft moving coca paste from Bolivia and Peru to the Colombian cocaine refineries. Small narco planes flew drugs out of clandestine airstrips, usually at night. The U.S. Air Force deployed ground-based radar teams to remote areas in Peru, Colombia, and Venezuela. When the host nation radar operators detected an illegal track, they would launch an interceptor aircraft to force the narco plane to land. The U.S. Air Force helped upgrade the host nation interceptor planes as well as the cargo planes flying supplies out to the counternarcotics units. ${ }^{22}$

The Special Forces JPATs worked out of the Military Group offices inside the embassy. They walked all counternarcotics mission paperwork around to the U.S. country team offices for interagency clearance. They coordinated memorandums of understanding with the Ministry of Defense, visited the police academies to verify the selection and assessment processes, and assisted with the planning for counternarcotics operations. They hunted down supplies and equipment for the teams in the jungle camps, coordinated the airlift to move the loads, briefed incoming teams on force protection, and found them secure lodging in the local hotels. They acted as the eyes and ears for the special operations command component of SOUTHCOM, known as Special Operations Command South (SOCSOUTH), which commanded the mission.

Soon, the Special Forces TATs and JPATs became indispensable. They were the glue that held the U.S. Embassy efforts together. The Special Forces soldiers used their rapport-building skills to improve contacts at the highest levels of the armed forces and the police, which would pay dividends over the next 30 years.

\section{Case study: Colombia}

By 1997, the Air Bridge Denial program had degraded the air movement of cocaine base from Bolivia and Peru into Colombia. The interceptor aircraft interdicted more than 100 planes a year. Most narco planes were intercepted while offloading on clandestine airstrips, but they were also occasionally shot down while in flight. ${ }^{23}$ The narcos adapted by ramping up the coca field cultivations in Colombia, from 44,000 hectares 
in 1994 to 163,000 hectares by $2000 .{ }^{24}$ As a result, the air movement from Peru was no longer essential. The farmers in Colombia could now grow the coca, make the cocaine base, and move the product to the labs by river, road, or mule.

Growing coca in Colombia had advantages. The country had a plentiful 1.6 million hectares of land suitable for coca cultivation, far beyond world demand, which could be met with only 225,000 hectares. ${ }^{25}$ The best coca-growing areas in Colombia were also in ungoverned or under-governed spaces, far away from the Colombian security forces, who were preoccupied with the 37-year conflict against the 15,000-strong leftist FARC; the 5,000-strong National Liberation Army; and the 20,000 members of the right-wing paramilitary group, the United Self-Defense Forces of Colombia, also known as the "paramilitaries." ${ }^{26}$ The Colombian security forces had few resources and little energy remaining to counter the narcotrafficking surge.

The FARC, the National Liberation Army, and the United Self-Defense Forces seized the opportunity to extort the coca farmers in their areas of operation. They encouraged farmers to grow coca and provided the farmers with fertilizer and farm equipment. These groups also controlled the cocaine and chemical precursor shipping routes. The DEA estimated that the FARC alone was making more than $\$ 600$ million a year taxing the narcotraffickers. ${ }^{27}$ These additional funds gave the FARC the ability to double in size from 7,000 to 15,000 combatants in five years. ${ }^{28}$ Drug trafficking financed the illegal armed groups.

While centralization might have been viewed as a good business decision, Luis Moreno, the director of the U.S. State Department's Narcotics Affairs Section at Embassy Bogota, saw this as a golden opportunity to hit the narco trade head-on. "They have all their eggs in one basket," Moreno explained. "They have made it easy for us. We no longer have to fight a narcotrafficking operation dispersed over several borders. We can surge here in Colombia and hit them with a knockout punch." 29

The U.S. government lacked new foreign assistance funding, but the Defense Department and State Department creatively moved funds from other programs to Colombia. The embassy's Narcotics Affairs Section set up a second aerial fumigation spray base. The Military Group brought in more training teams for maritime, riverine, and ground interdiction.

This U.S. aid, however, was not without restrictions. The U.S. government limited assistance to Colombia for counternarcotics only. It prohibited the embassy from helping Colombia in their fight against the illegal armed groups: the FARC, the National Liberation Army, and the United Self-Defense Forces. The U.S. government did not want to go down a "slippery slope" and become locked in an internal conflict, another Vietnam. Any help the embassy provided had to be related to counternarcotics.

The U.S. government monitored the embassy for compliance. When the Colombians requested training or equipment upgrades, they had to show that more than $50 \%$ of the operational hours for that entity were for antinarcotics activities. Likewise, any intelligence that the U.S. government provided had to be related to narcotics activity. ${ }^{30}$

\section{Getting the Colombian Army into the fight}

The 180,000-strong Colombian Army was the largest component of the Colombian security forces. They were, however, the only service not supporting the counternarcotics effort. This was not unique to Colombia. None of the Andean Ridge armies were keen on supporting counternarcotics missions: counterinsurgency was their mission, while counternarcotics was viewed as a police mission. The army wanted to portray itself as the "friend of the people" and did not relish alienating farmers by eradicating their coca crops. ${ }^{31}$ This attitude, unfortunately, turned out to be short sighted. By the 1990s, the insurgent groups were using the coca trade to finance their operations, and the two activities could no longer be separated.

In 1997, the Military Group tried to open the door to the Colombian Army for counternarcotics participation. The Military Group sent 7th Group teams to train the Colombian Army's 12th and 24th brigades in the southern coca-growing departments of Caqueta and Putumayo. Because coca cultivations 
carpeted the brigades' operational areas, the embassy could make the case for the counternarcotics nexus. During patrols, the brigades often found and destroyed coca base labs and precursor chemicals.

The 7th Group teams only had limited success, because $70 \%$ of the Colombian Army were draftees on one- to two-year enlistments. It was not uncommon for enlistments to expire only days after graduating from their eight-week light infantry courses. Additionally, the small 350-man Colombian Army battalions had only three officers: the commander, one dual-hatted as the intelligence and operations officer, and one as the personnel and logistics officer. Likewise, their noncommissioned officer ranks were also thin. Thus, the 7th Group trainers found it impossible to implement a "train the trainer" concept.

On December 3, 1998, SOUTHCOM Commander General Charles Wilhelm approached General Fernando Tapias and the Colombian Joint Staff while at the Conference of Ministers of Defense of the Americas in Cartagena. "How about creating an elite Army counterdrug battalion?" Wilhelm asked. "This unit would be all professional career soldiers. It would be properly staffed." 32

"We will have to think about that," replied Tapias. The Colombian Army was still reluctant to be pulled into the counternarcotics mission, and they also worried that any U.S. government assistance to a new counterdrug battalion might come with "strings attached" and impinge on their sovereignty. ${ }^{33}$

"The FARC are getting stronger every day from the narco trade," said Wilhelm. "You can't keep fighting this conflict like business as usual. What you are doing now is not working." Tapias agreed. "I can provide some training and some non-lethal field gear," said Wilhelm. "That is all I can promise. The rest will be up to you." 34

\section{Mission planning}

With Tapias' support, SOUTHCOM set out to help build the counterdrug battalion, modeling it after a U.S. Army Ranger battalion. The battalion would include 938 professional soldiers, including a staff of 46 officers and senior noncommissioned officers. The unit would be like no other Colombian unit. SOUTHCOM wanted to start building the force by April 20, 1999, which was less than 90 days away. It was a very ambitious timeline, but Wilhelm wanted to strike while Colombian interest was still high.

SOCSOUTH tasked the 7th Group with the mission. Its deputy commander, Lieutenant Colonel Bruce Yost, led the planning effort. He had recently returned from a two-year tour in the Military Group Colombia as the Army mission chief, and he knew all the key players in the country. Yost needed every bit of his rapport-building skills to overcome the resistance he met.

The compressed timeline and the size of the project took the Colombian military and U.S. Embassy officials by surprise. Yost convinced them to agree that Tolemaida, the Colombian National Training Center, would be the ideal training location. Ultimately, the Colombians agreed to train the 938-strong counterdrug battalion in three nine-week iterations of 300 students, from April through December 1999.

To fund training, the SOCSOUTH commander canceled other missions: 7th Group's remaining 1999 training missions to the 12th and 24th brigades and two Navy SEAL deployments to Cartagena. It leveraged "free" airlift to Colombia thanks to Chief Warrant Officer Larry Plesser, the 7th Group air planner, who had forged a special relationship with Air National Guard units around the United States. Plesser acquired the sizable airlift of C-17 and C-141 cargo planes to transport the 7th Group trainers and their equipment from Fort Bragg to Colombia.

"Instead of punching holes over the skies of North Carolina for your annual pilot qualification testing, why don't you fly our men down to Colombia?" Plesser asked..$^{35}$ The Air National Guard loved the excitement of landing on new airfields and supporting an important mission, all the while fulfilling their annual training requirements. Plesser performed similar coordination for all 7th Group missions into Latin America. As a result, SOUTHCOM could afford to double the 7th Group's operational tempo from 75 to 150 missions annually. Plesser singlehandedly expanded military-to-military contacts with all 26 countries in the region. ${ }^{36}$ 
SOCSOUTH planners flew to Camp Shelby, Mississippi, in February 1999 to meet with the 7th Group commander. Colonel Ed Phillips ran a national-level special operations training exercise covering five states and involving 2,000 soldiers, sailors, and airmen. He was a meticulous planner and often had to defend his 18-month training calendar against outside encroachment, and the counterdrug battalion mission would be a major disruption. But Phillips understood the importance of the mission. "Give me two hours," said Phillips, after listening to the planning team before disappearing behind a curtain on the gymnasium stage. Soon, he emerged with the nine-month training calendar that included the rotation plan for the three Special Forces companies.

"This mission needs to be done by an entire Special Forces company, all six ODAs," said Phillips.

We will divide the initial 300 students into six 50-man groups. Each ODA will run a training committee. The student groups will do a round-robin rotation through each committee. We will have committees for weapons, medical skills, land navigation, patrolling, communications, and operations planning. For the last three weeks we will bring everyone together for full mission profile exercises. ${ }^{37}$

Phillips understood the mission, having executed similar ones in 15 Latin American countries in the past. He had commanded at every level in the Group: detachment, company, battalion, and now group. Special Forces emphasizes regional focus, and Phillips was a product of that system.

By April 1999, the 7th Group was ready to launch from Fort Bragg, but General Hugh Shelton, the chairman of the Joint Chiefs of Staff, had not yet signed the deployment order. The Joint Staff was awaiting confirmation that all Colombian Army soldiers slated for the training had been vetted under the provisions of the "Leahy Law" in the United States..$^{38}$ Under the 1997 law, Congress banned the United States from providing training or aid to a foreign military unit whose members had violated human rights. Three days prior to the proposed deployment date, the State Department completed the vetting.

Days later, the first Special Forces company landed on the 10,000-foot runway of Tolemaida, the "Fort Benning of Colombia," home of their International Lancero School, Airborne School, and National Training Center. Captain Eric Valentzas, a 7th Group veteran, was on a two-year assignment as an instructor at the Lancero School. Together, Valentzas and the JPAT paved the way for the incoming Special Forces company. They performed the advance work of coordinating the billeting, office space, firing ranges, and maneuver areas for the company and their 300 students.

The Colombian Army created the Lancero School in 1955. Captain Ralph Pucket and First Lieutenant John Galvin helped establish the school. ${ }^{39}$ Modeled after the U.S. Army Ranger School, the Colombian Army sends officers and noncommissioned officers to the 73-day course. Since 1955, there have been more than 17,000 graduates and 581 international graduates from 18 different countries, including more than 100 from the 7th Group (including this handbook's co-editor, Michael A. Sheehan). Those who wear the coveted Lancero badge establish instant bona fides in Colombia. Four of the incoming 80 trainers were Lancero graduates. ${ }^{40}$

\section{Training the counterdrug battalion and the move to Tres Esquinas}

Initially, the Tolemaida base proved an ideal learning environment. Everything went according to schedule. The students were motivated, and the Colombian Army leadership was engaged. But Lieutenant Colonel Jeff Waddell, the commander of 7th Group's 1st Battalion, had concerns about the last phase of the course. "This Tolemaida cow-pasture is like walking around a golf course," Waddell said. "We need to take the final exercise down south to the Putumayo jungle, where these boys are going to have to fight."

In response, the Colombian Air Force shuttled the students and their trainers from the pleasant meadowlands of Tolemaida to the Amazon rainforests of the Tres Esquinas Air Base, 418 kilometers away, for 
the final training exercise. The base had been carved out of the jungle during the Colombia-Peru War of 1932. It sits at the junction of two great rivers and is accessible only by air or a three-day river trip through FARC territory.

The hot, humid air blasted the Special Forces trainers as the plane's ramp opened after landing. There were no structures available to occupy; it was a bare-bones field situation. Tres Esquinas had a few Colombian Air Force office buildings, a Colombian Riverine Marine outpost, and the Colombian Joint Intelligence Center tent. The 400-man Colombian Air Force airbase defense force lived in their foxholes, scattered around the porous six-kilometer perimeter.

The Special Forces soldiers savored the challenge. Constructing the base would be time consuming and would negatively impact training, but the trainers would not let it be a distraction. This was an opportunity to show the new students how to thrive in an austere environment.

They needed to establish better security because the 48th FARC Front, and its estimated 4,000 fighters, sat just outside the base's perimeter. The area was a major coca-producing region, and the 48th Front's primary mission was to manage the extensive coca trade in the Putumayo Department. They not only taxed the coca growers, but they controlled the entire production chain. These drug funds helped sustain 15,000 FARC guerrillas. Estimates of the FARC's annual income ranged from $\$ 200$ million to $\$ 3.5$ billion. ${ }^{42}$ The coca trade accounted for the majority, but kidnapping and extortion were also significant sources of revenue, with kidnapping accounting for $\$ 300$ million at its peak. ${ }^{43}$

The 7th Group knew the FARC viewed the counterdrug battalion as a serious threat to their financial operations and concluded that a FARC attack on Tres Esquinas was imminent. The FARC could exploit a successful attack against the U.S. trainers to gain international credibility and derail U.S. government assistance efforts.

\section{Special Forces engineers and weapons sergeants strengthen the perimeter}

Waddell was not going to make it easy for the FARC. His Special Forces engineers and weapons sergeants strengthened the defenses. The Group needed barrier material to improve the perimeter and build fortifications but lacked the supplies or funds to purchase them. Major General Phillip Kensinger, commander of U.S. Army South in Panama, came to the rescue. A former 7th Group officer, Kensinger had led the mission to train and equip the Honduran Army against the Sandinistas in 1982. He caught wind of the plight of his former comrades and had excess barrier material.

After 88 years in Panama, U.S. Army South was relocating to Fort Buchanan, Puerto Rico. Kensinger made use of the Defense Department's Excess Defense Articles program. He sent kilometers of concertina and razor wire and tons of sandbags, stakes, and pickets to Tres Esquinas. Excess defense articles are Department of Defense-owned articles that are no longer needed. The United States can give this surplus equipment at no cost to foreign recipients on an "as is, where is" basis in support of U.S. national security and foreign policy objectives. ${ }^{44}$ Once again, Plesser contracted the Air National Guard to help move the material.

Special Forces engineer sergeants are demolitions experts and skilled builders, and they led the effort to harden the perimeter. They designed field fortifications that could withstand machine-gun and mortar fire. They strung wire, built bunkers, cut down trees for observation towers, and marked trench lines. It was hard work in the tropic sun, but few complained.

The Special Forces weapons sergeants established a Guard Operations Center, and a 30-man truckmobile quick reaction force. They went from fighting position to fighting position and developed range cards for crew-served weapons. They also formed an interior guard force to protect the flight line and sensitive locations inside the perimeter. They developed a patrolling plan and emplaced listening and observation posts outside the perimeter to detect and thwart FARC attacks. They ran full-blown, no-notice live fire rehearsals of the base defense plan. These exercises included mortars, the Colombian Air Force AC-47 Fantasma gunship, and the Colombian Marines Piranha patrol boats. 
The base defense has withstood the test of time. Since 1999, the FARC has failed to penetrate the perimeter despite several attempts, and Colombian Army commanders around the country have copied many of the techniques that were employed at Tres Esquinas.

\section{Special Forces medics protecting the force}

The 48th Front was a threat, but an immediate danger was already "inside the wire": insects, wildlife, and bacteria. The Special Forces medics developed and supervised the preventive medicine plan. Clouds of mosquitoes appeared at dawn and dusk, carrying dengue, malaria, and yellow fever. The Brazilian wandering spider, the most venomous arachnid in the world, roamed the base camp. ${ }^{45}$ The poison dart frog lay hidden in the rotting wood, waiting for a student patrol to pass by. The bullet ant, named for its potent sting, made victims wish they had been shot with a bullet.

The Orteguaza River flowed with surprises. The electric eel could deliver a massive electric shock, enough to stun the victim into drowning. The black caiman prowled the riverbanks, and schools of piranhas glided past the base.

Most aggravating was the tiny, biting, bloodsucking sand fly. The "no-see-ums" could penetrate the fine mesh of the mosquito nets. The sand fly carried Leishmaniasis, causing ulcers on the skin, mouth, and nose; fever; enlargement of spleen and liver; and a lower red blood cell count. As the students ran through the jungle, they brushed against poisonous plants, triggering strong allergic reactions and severe skin rashes. Thorns punctured their skin and caused infections.

The Special Forces medics provided classes on the native species. They swept the camp to eradicate likely hiding spots, standing water, and breeding areas. They treated the bed nets with insecticide and distributed anti-malarial pills. Men shook out their clothes in the morning and kept their sleeves rolled down and hats on. The medics forced the men to drink water as they acclimated to the humidity and heat.

There was also the invisible enemy: the deadly bacteria that transmit giardia, diphtheria, typhoid fever, cholera, and dysentery. The medics erected burn-out latrines, urinal pipes, hand-washing stations, field showers, and water purification systems. Good personal hygiene would reduce the infestation of body lice and mites. It was a point of pride for the medics to keep the non-battle injury rate to zero. The medics supervised the kitchen to identify spoiled or undercooked food, and they treated the river water with their reverse osmosis water purifiers. They moved garbage and rubbish to a landfill outside the camp.

The medics and the counterdrug battalion also ran a medical civic action in the nearby village of Solano. This was a common 7th Group practice in Latin America. ${ }^{46}$ They would win the goodwill of the people, learn about the local attitudes, and possibly gain valuable information from the satisfied villagers.

In its first three days, the civic action saw more than 800 patients. The medics performed minor surgeries, optometric evaluations, pediatrics, and health screening referrals. For the next 20-plus years, the counterdrug battalion would be operating in similar inhospitable environments, and the Special Forces medics taught them how to stay healthy.

\section{The formation of Plan Colombia}

Back in Bogota, Colombian President Andres Pastrana was meeting with the "big four": General Barry McCaffrey, the director of the Office of National Drug Control Policy; Brian Sheridan, assistant secretary of defense for special operations and low-intensity conflict; General Wilhelm, SOUTHCOM commander; and Rand Beers, assistant secretary of state for international narcotics and law enforcement affairs. ${ }^{47}$

Pastrana lamented that his daring peace overture to the FARC was proving disastrous. A year earlier, Pastrana had created a 42,000-square-kilometer demilitarized zone for negotiations to bring an end to the 
conflict, but the FARC did not honor the agreement and instead used the sanctuary to refit and rearm. The FARC's ranks swelled to $15,000 .^{48}$ In the previous year, there had been more than 2,800 kidnappings, ${ }^{49} 176$ police station attacks, ${ }^{50} 1.8$ million people displaced, ${ }^{51}$ and the cocaine trade had erupted. ${ }^{52}$

Pastrana proposed a comprehensive "Plan Colombia" aid package. He needed increased U.S. support to stabilize the situation. His integrated strategy would secure help for counternarcotics projects, bolster economic development, strengthen the government's presence in outlying areas, and increase humanitarian aid.

The "big four" led the U.S. interagency effort to promote Plan Colombia to President Bill Clinton and the U.S. Congress. By limiting the plan to counternarcotics, they alleviated concern that the United States would get pulled into Colombia's internal conflicts. The proposal included reinforcing all ongoing counternarcotics programs: Riverine, Air Bridge Denial, Maritime, Aerial Eradication, Antinarcotics Police, and Alternative Development.

The Plan Colombia program would bolster the new and heretofore unfunded counterdrug battalion. The "big four" flew to Tres Esquinas to consult with the 7th Group trainers and to determine what kind of support the battalion needed. As Wilhelm landed, the students had just returned from a three-day field exercise to burn three coca base labs. They had walked day and night through dense jungle for five kilometers. While a short distance on the map, it was a grueling walk in real life.

Three coca base labs were not much to show for three days of work, when considering there were an estimated 10,000 base labs and 150 cocaine labs in Colombia. At this rate, the battalion would not make a dent in the drug supply. Air mobility was the answer. It was prescient that Waddell chose to move the training to the dense jungle. There, the government visitors got a clear sense of the challenges facing the Colombians. Thus, indirectly, the 7th Group helped shape Plan Colombia.

Senator John McCain believed in Plan Colombia and visited the training in Tres Esquinas. "Do we need more than one [counterdrug] battalion? If so, how many?" McCain asked. "How about a [counterdrug] brigade? Three battalions? Let's not nickel and dime this. The Colombians need our help. Let's go in hard and make a difference."

"How about air mobility?" inquired McCain. "How many Blackhawks would it take to move this [counterdrug] brigade around to get the job done?" The Military Group aviation advisor quickly responded, "30 Blackhawks, sir." He already knew the answer and was hoping to be asked. ${ }^{53}$

\section{Plan Colombia officially begins}

President Clinton signed Plan Colombia in July 2000. It was a $\$ 1.3$-billion program ${ }^{54}$ that would exceed $\$ 7$ billion over the next decade..$^{55}$ The plan aimed at fighting the illicit drug trade, increasing the rule of law, protecting human rights, expanding economic development, and instituting judicial reform. The cornerstone of Plan Colombia was the counterdrug brigade and the Army aviation brigade. Murray's "30 Blackhawks" would ultimately become 72 helicopters. ${ }^{56}$

The first counterdrug battalion became operational on December 15, 1999, and the next two in 2000 and 2001. The counterdrug brigade headquarters was activated on December 8, 2000. The brigade focused its operations in the departments of Putumayo, Caquetá, and Nariño, all centers for coca production. With the benefit of air mobility, the brigade inflicted casualties on guerrilla forces and disrupted coca harvesting and processing. The brigade worked with the National Police to secure coca-producing areas for spraying as part of the aerial eradication program, dramatically reducing ground fire incidents.

The brigade strengthened the Colombian government's ability to extend its authority throughout Colombia and played a key role in attacking the sources of insecurity in Colombia in the remote rural areas. The brigade became the "force of choice" for the government of Colombia to capture high-value targets, such as narcotrafficking and criminal organization leadership. 


\section{7th Group and the Colombian National Police}

In addition to the Colombian Army Counterdrug Brigade, the 7th Group worked closely with the National Police. After building the counterdrug brigade, the 7th Group modified its footprint in Colombia to four ODAs - two working with the National Police and two with the Army-and expanded the JPAT into a 15-man Special Forces Operational Detachment Bravo, led by a Special Forces company commander, that formed an advanced operations base in Bogota. The advanced operations base controlled the team missions and interfaced with the Military Group, SOCSOUTH, the Embassy's Narcotics Affairs Section, and the Colombian Army and National Police.

Since 1989, an ODA had been assigned to train and assist the National Police's elite Jungla Comandos. Under Plan Colombia, the Junglas would expand from one company to four, a total of 600 men. The Narcotics Affairs Section provided an annual budget of $\$ 5$ million, and the ODA supervised the training of the Jungla training cadre and the three Jungla airmobile companies. The Junglas' primary missions were the destruction of cocaine labs and the capture of the narcotraffickers. The Jungla operations relied heavily on police aviation, which enabled them to reach their remote and inaccessible targets. The Junglas seized over 50 metric tons of cocaine and destroyed hundreds of laboratories annually. ${ }^{57}$

The ODA helped the Colombian government establish a police presence in the rural areas. Over the course of the decades-long conflict, the National Police had abandoned many towns in the remote areas due to FARC attacks. The FARC subsequently assassinated mayors, impressed minors into their ranks, kidnapped for ransom, extorted business owners, and forced farmers to grow coca. Civilians often fled to the safety of the urban areas.

In April 2002, President Alvaro Uribe directed that Colombia's security forces reestablish a police presence in the 158 unmanned municipalities (of the country's 1,098 municipalities). The Narcotics Affairs Section Bogota provided $\$ 1.5$ million to equip each squadron, and the 7 th Group trainers helped design and train the 10,000-man rural police force, the Carabinero Mobile Squadrons. These Mobile Squadrons were trained to operate in high-threat areas and included civil affairs, agricultural, and veterinarian officers to interface with the local population.

From April 2003 through September 2004, the National Police installed detachments, ranging from 45 to 250 police, in the 158 unmanned municipalities. The simultaneous deployment of the Carabinero Squadrons and Municipal Police detachments provided a fine net of security over Colombia's countryside. The FARC attacks, kidnappings, extortion, and narcotrafficking all drastically dropped. Mayors and displaced civilians returned to the towns, and nongovernmental organizations and U.S. Agency for International Development workers now operate safely in many of these zones.

\section{Conclusion}

On November 30, 2016, the Colombian government ratified a peace agreement with the FARC. ${ }^{5}$ With a relatively small footprint, the 7 th Group trainers made a significant contribution to ending the 50 -year conflict. Most notably, the 7th Group-trained counterdrug brigade and the Antinarcotics Police Jungla Comandos captured (or killed) hundreds of FARC rebels, seized hundreds of tons of cocaine, and dismantled thousands of processing laboratories, which severely disrupted narcotrafficking organizations and drove the FARC to the bargaining table.

But the groundwork was laid more than a decade prior, starting with Captain Cleveland's first mission in Bolivia in 1987. This long-term investment provided the 7th Special Forces Group with the language proficiency, cultural skills, expertise, and rapport to both shape and execute Plan Colombia years later. The Special Forces trainers taught the fieldcraft skills that the Colombians needed to make high-risk arrests of heavily armed criminal elements operating in difficult terrain. 
The Special Forces trainers shared their hard-earned experiences in counternarcotics operations in the Andean Region with the Colombian security forces. They showed devotion, patience, and attention to detail in forming the leaders. They were superb role models. The 7th Group training program in Colombia is an example of how a long-term yet modest investment can have outsized results and the wisdom of investing in partner nations before crises erupt.

\section{Notes}

1 Kevin Higgins served as the Military Group commander, U.S. Embassy Bogota, from 1999-2001, and helped design and execute Plan Colombia.

2 The Military Assistance Training Advisor course, established in the 1960s at Fort Bragg, included the "MATA mile," a circuit training course in the training area at Fort Bragg. Although the course ceased to exist decades ago, the fitness trail is still referred to as the MATA mile.

3 Author served as Wayne Downing's deputy inspector general for inspections from 1990-1992.

4 Special Operations Command, ARSOF Fact Book (Fort Bragg: U.S. Army, no date).

5 Author recollection of the 1995 flight.

6 Rand Beers, "Plan Colombia Is Well Worth U.S. Support," Boston Globe, July 9, 2001.

7 White House, National Drug Control Strategy: Progress on the War on Drugs, 1989-1992 (Washington, DC: White House, 1993) 27-28.

8 Author recollection of story frequently told by Leveron.

9 Author experience based on Congressional delegations, Congressional staff delegations, and journalist visits.

10 Ibid.

11 A detachment, or "A Team," consists of 12 Special Forces soldiers or "Green Berets": The commander (an officer), an assistant detachment commander (a warrant officer), a team sergeant, an intelligence sergeant, two weapon sergeants, two engineering sergeants, two communications sergeants, and two medical sergeants.

12 Charles Cleveland, The American Way of Irregular War: An Analytical Memoir (Santa Monica: RAND), 31-32.

13 Author recollection of story recounted by Master Sergeant Stan Brown in August 1989.

14 The course was renamed Garras de Valor, or Claws of Valor, in 1990. See www.felcn.gob.bo/CEIAGAVA/QuienesSomos.aspx.

15 Author supervised the transition.

16 Guillermo Bullaín Iñiguez, " “Claws of Valor' in the Jungle," Correo del Sur, October 10, 2016.

17 Author visited Sacolick at the Sinchis camp in 1989.

18 Author recollection of conversation with DEA agent in 1989.

19 Author recollection of conversation with Stan Brown in Bolivia in 1989.

20 Army Intelligence Center, Student Handbook (Fort Huachuca: U.S. Army Intelligence Center, 1995).

21 Ibid.

22 Matthew Bates, "U.S., Colombian Governments Work to Deter Drug Trafficking," Air Force Print News, September 21, 2016, www.af.mil/News/Article-Display/Article/129685/us-colombian-governments-work-toto-deter-drug-trafficking/.

23 U.S. Government Accountability Office, Air Bridge Denial Program in Colombia Has Implemented New Safeguards, but Its Effect on Drug Trafficking Is Not Clear (Washington, DC: U.S. Government Accountability Office, 2005).

24 Office on Drugs and Crime, Colombia: Coca Survey for December 2002 (New York: United Nations, 2003), 3.

25 "Colombia-Arable Acres," Trading Economics, accessed October 25, 2020, https://tradingeconomics.com/colom bia/arable-land-hectares-wb-data.html; Office on Drugs and Crime, World Drug Report 2010 (Washington, DC: United Nations, 2011), 66.

26 These are widely accepted estimates of each group's size.

27 “The World's 10 Richest Terrorist Organizations," Forbes, December 12, 2014, www.forbes.com/sites/forbes international/2014/12/12/the-worlds-10-richest-terrorist-organizations/.

28 Alfredo Rangel Suárez, Colombia: guerra en el fin de siglo (Bogotá: Tercer Mundo, 1998), 12.

29 Author recollection of conversations with Luis Moreno.

30 Author experience as Military Group commander from 1999-2001.

31 Joseph Treaster et al., "Battle Against Cocaine Traffic Is Languishing in South America," New York Times, January 1, 1990, www.nytimes.com/1990/01/01/world/faltering-drug-war-flow-latin-american-special-report-battle-againstcocaine.html.

32 Author recollection of meeting. 
33 Ibid.

34 Ibid.

35 Author recollection of conversation with Larry Plesser.

36 SOUTHCOM is now responsible for 31 countries. See "Area of Responsibility," U.S. Southern Command, accessed September 16, 2020, www.southcom.mil/About/Area-of-Responsibility.

37 Author recollection of event.

38 Bureau of Democracy, Human Rights, and Labor, "Leahy Law Fact Sheet," U.S. Department of State, January 22, 2019.

39 John Galvin, Fighting the Cold War, A Soldier's Memoir (Lexington: University Press of Kentucky, 2015), 63-83.

40 Charles Briscoe, "Colombian Lancero School Roots," Veritas 2, no. 4 (2006): 30-37.

41 Author recollection of conversation with Jeff Waddell.

42 Mimi Yagoub, "What the FARC's Elusive Finances Mean for Peace," InSight Crime, April 20, 2016, www.insightcrime.org/news/analysis/what-the-farc-s-elusive-finances-mean-for-peace/.

43 "The FARC's Finances: Unfunny Money," The Economist, April 14, 2016, www.economist.com/the-americas/ 2016/04/14/unfunny-money; “The FAR C's Riches: Up to \$580 Million in Annual Income,” InSight Crime, September 16, 2017, www.insightcrime.org/news/analysis/farc-riches-yearly-income-up-to-580-million/.

44 “Excess Defense Articles (EDA)," Defense Security Cooperation Agency, accessed September 16, 2020, www.dsca.mil/ programs/excess-defense-articles-eda.

45 Tim MacWelch, "The 10 Most Dangerous Spiders in the World," Outdoor Life, November 11, 2019, www.out doorlife.com/photos/gallery/survival/2011/10/10-most-dangerous-spiders-world/.

46 Steve Balestrieri, "Civic Action Projects Very Important in Special Operations Missions," SOFREP, August 1, 2017, https://sofrep.com/specialoperations/civic-action-projects-important-special-operations-missions/.

47 Author helped coordinate this meeting.

48 Suárez, Colombia, 12.

49 U.S. Bureau of Citizenship and Immigration, Colombia: Kidnapping and Extortion by Armed Groups in Urban and Suburban Areas (Washington, DC: U.S. Bureau of Citizenship and Immigration, 2000).

50 "Cómo va la guerra," Cambio, June 19-26, 2000.

51 Francis Deng, Internal Displacement in Colombia (Washington, DC: Brookings, 2000).

52 "Cocaine Production in Colombia Is at Record Highs," The Economist, July 6, 2019, www.economist.com/ the-americas/2019/07/06/cocaine-production-in-colombia-is-at-historic-highs.

53 Senator John McCain visited Colombia three times when the author was the Military Group commander.

54 Marc Lacey, "Clinton Defends the Outlay of \$1.3 Billion to Colombia," New York Times, August 24, 2000, www. nytimes.com/2000/08/24/world/clinton-defends-the-outlay-of-1.3-billion-to-colombia.html.

55 Rafael Romo, "Plan Colombia Revisited: Mixed Results for US-Anti-Drug Initiative," CNN, January 17, 2011, https://edition.cnn.com/2011/WORLD/americas/01/17/colombia.us.drugs/.

56 U.S. Government Accountability Office, Drug Reduction Goals Were Not Fully Met, but Security Has Improved (Washington, DC: U.S. Government Accountability Office, 2008), 29.

57 Author experience; "Run Through the Jungle," Small Wars Journal, November 22, 2011, https://smallwarsjournal. $\mathrm{com} / \mathrm{blog} /$ run-through-the-jungle-colombia's-jungla-commandos.

58 Nicholas Casey, "Colombia's Congress Approves Peace Accord With FARC," New York Times, November 30, 2016, www.nytimes.com/2016/11/30/world/americas/colombia-farc-accord-juan-manuel-santos.html. 